\title{
EVALUATION OF EXTERNAL STRATEGIC ANALYSES BY AHP METHOD
}

\author{
[Vyhodnocení strategické analýzy externího prostředí metodou AHP] \\ Terezie Bartusková ${ }^{1}$ \\ ${ }^{1}$ Vysoká škola báňská-Technická univerzita Ostrava, Ekonomická fakulta, Sokolská 33, 70121 Ostrava \\ Email:terezie.bartuskova@vsb.cz.
}

\begin{abstract}
Strategic analysis is the first step of strategic management. There are many methods of strategic analysis which are used for external and internal environment description. The paper is focused on SWOT analysis, which is the most frequently used method and which enables synthesis of partial results of external and internal analyses; special attention is given on the external analysis. In the paper the proposal of the evaluation is suggested and on this basis external part of SWOT matrix, which consist of opportunities and threats, is created. For the evaluation the method of analytic hierarchy process (AHP) is used and this methodology is applied on the data of the selected company. Opportunities and threats that have been found by this methodology are compared with results obtained by the company management.
\end{abstract}

Keywords: AHP, external environment, strategic analysis, SWOT analysis.

JEL classification: C51, L10

Doručeno redakci: 18.5.2015; Recenzováno: 25.5.2015; 26.5.2015; 26.6.2015; Schváleno k publikování: 23.9.2015

\section{Úvod}

Strategická analýza je základním krokem při realizaci strategického řízení organizace, pomocí jejichž metod lze zmapovat podmínky vnějšího a vnitřního prostředí organizace. Hlavním cílem strategické analýzy není pouze popsat okolní prostředí organizace, ale je také důležité vyhodnotit, které faktory mají největší význam pro strategické rozhodování a jak významný je vliv těchto jednotlivých faktorů. Je důležité provést syntézu dílčích výsledků a tím získat ucelený obraz o okolním prostředí organizace. Velmi často používanou metodou strategické analýzy je SWOT analýza (Grasseová, et al., 2010, Afonina, 2011).

Syntéza výsledků dílčích analýz není jednoduchá a při uplatňování navržených metod se objevují chyby, které budou v článku uvedeny. Tento prŕspěvek je zaměřen na analýzu vnějšího okolí.

Cílem je navrhnout způsob vyhodnocení výsledků dílčích metod externí analýzy tak, aby tvořily vstupní data pro tu část SWOT matice, které se zabývá externí analýzou, tedy aby bylo možno identifikovat př́ležitosti a hrozby podniku. Nejprve budou popsána teoretická východiska SWOT analýzy a vnější analýzy prostředí a bude poukázáno na slabiny SWOT analýzy. Ve druhé části článku je pak navržena metodika, která s využitím analytického hierarchického procesu pomůže sestavit SWOT matici.

\section{Teoretická východiska strategického řízení a strategické analýzy}

Středem procesu strategického řízení stojí výběr strategie a je realizováno především vrcholovými představiteli organizace. Zahrnuje činnosti zaměřené na udržování dlouhodobého souladu mezi posláním organizace a vnějším prostředím, v němž organizace působí. V procesu strategického rrízení je využívána celá řada nástrojů, které jej usnadňují 
$\mathrm{v}$ celém jeho procesu, zejména $\mathrm{v}$ analýze interního a externího prostředí, v prognózování i formulaci cílů (Grasseová, et al., 2010, Fotr et al., 2012).

Prvním krokem strategického řízení je strategická analýza. Je to klíčová činnost celého strategického řízení a soustředí se na podrobné zkoumání nebo hodnocení vnějšího a vnitřního prostředí (Grasseová et al., 2010). Cílem strategické analýzy je identifikovat, analyzovat a ohodnotit všechny relevantní faktory, o nichž lze předpokládat, že budou mít vliv na konečnou volbu cílů a formulaci strategii organizace. Výsledky strategické analýzy nám musí dát odpověd’ na dvě otázky: Kde se nacházíme? Kam můžeme směrovat?

Chce-li organizace přijmout správné rozhodnutí, musí vypracovat nejprve potřebnou informační základnu. Ta je složena především z informací o současné a budoucí pozici firmy vzhledem ke svému okolí a také z informací týkající se konkurentů firmy. Toto vyžaduje důkladné provedení jak externí analýzy (analýzy vnějšího prostředí), která nám umožní zmapovat a zhodnotit externí prostředí, ve kterém se podnik pohybuje a je jím ovlivňován, tak interní analýzy, díky níž podnik analyzuje své interní prostředí (vnitřní prostředí), tedy např. analýzu procesů a potenciálů podniku. Nejde jen o to popsat současný stav, ale také prognózovat jeho budoucí vývoj, což bude mít na rozhodování o budoucí strategii zásadní vliv (Williamson et al., 2004, Fotr, et al., 2012, Henry, 2011).

V rámci strategické analýzy provádíme zpravidla následující činnosti, přičemž pořadí je možné přizpůsobit vlastním potřebám (Grasseová et al., 2010). Jsou to následující:

- revize regulátorů řízení a zhodnocení implementace dosavadních strategických dokumentů, což spočívá v revizi zákonů, vyhlášek, norem apod., aby si organizace dokázala udělat představu o změnách, které mohou ovlivnit směr strategické analýzy a stanovení strategického zaměření,

- analýza zainteresovaných stran, jimiž mohou být zákazníci, partneři, zaměstnanci, vlastníci, vláda a legislativní orgány i celá společnost s cílem porozumět jejich očekávání a potřebám,

- strategická analýza vnějšího prostředí, jejímž cílem je prozkoumání prostředí, ve kterém společnost funguje a poznání možných př́ležitostí a hrozeb,

- strategická analýza vnitřního prostředí, což je celkový audit výchozí situace organizace a definování všech zdrojů, a posledním krokem je

- syntéza s využitím SWOT analýzy.

Jak bylo uvedeno, poslední krok strategické analýzy je syntéza výsledků. Znamená to tedy, že je potřeba vyhodnotit jak výsledky jednotlivých oblastí, tak také jejich vzájemný vztah. Pro svou komplexnost a přehlednost (Afonina, 2011, Grasseová et al., 2010) je často využívána právě SWOT analýza.

\subsection{SWOT analýza}

SWOT analýza je koncepční rámec pro systematickou analýzu, zaměřený na charakteristiku klíčových faktorů ovlivňujících strategické postavení podniku (Sedláčková, 2000, s. 78). Název analýzy je odvozen od čtyř anglických slov Strengths (silné stránky), Weaknesses (slabé stránky), Opportunities (př́ležitosti) a Threats (hrozby). SWOT analýza je dělena na analýzu interní a analýzu externí. Aby mohl podnik dlouhodobě růst, musí se zabývat faktory, které umožní růst podniku a vyvarovat se těch, které by způsobily př́ípadný neúspěch. Často je také SWOT analýza označována jako integrující analytický nástroj (Grasseová et al., 2010 a první krok k formulaci strategie, viz např. (Ferrel, Hartline, 2014, Williamson et al., 2004, Griffin, 2007). 
Informační základnou pro externí a interní část SWOT analýzy jsou výsledky vybraných metod. Jak zdůrazňuje Keřkovský a Vykypěl (2006), je důležité dodržet zásady při zpracování SWOT analýzy. Mezi tyto zásady patří, že by závěry vyplývající z této analýzy měly být relevantní, že je potřeba soustředit se na významná fakta a jevy, identifikovat fakta strategické úrovně, je nutné být objektivní a ohodnotit jednotlivé faktory dle jejich důležitosti.

SWOT analýza je jako metoda strategické analýzy ve firmách velmi oblíbená. Lze to doložit několika výzkumy, které proběhly jak na území české republiky (Baurová, Janečko, Papalová, 2013, Afonina, 2011), tak mimo něj (Tassabehji a Isherwood, 2014). Pokud shrneme výsledky výzkumů, které byly zaměřené na zjišt’ování využití nástrojů a metod strategické analýzy jak v českých podnicích, tak v zahraničí, lze konstatovat, že SWOT analýza zaujímá první, resp. 3. místo v pořadí, za analýzou finanční a analýzou cenovou.

\subsection{Kritické aspekty současné aplikace SWOT analýzy}

I přesto, že je SWOT analýza velmi oblíbená a hojně využívána, najdou se její kritici. Jako u každé metody záleží na kvalitě vstupních dat. Pokud ta nebude zabezpečena, nelze očekávat, že zjištěné výsledky SWOT analýzy budou relevantní. Zajistit dostatečně datovou základnu může být časově i finančně náročné. Je obtížné zhodnotit, do jaké míry se vyplatí investovat do datové základny čas a prostředky, vzhledem k př́nosům, které z těchto zjišsění plynou.

Hill a Westbrook (1997) ve svém kritickém článku vymezili tyto zásadní chyby. Aplikace SWOT analýzy v praxi se často stává jen sepsáním odrážek. Při zpracování chybí metodika. Tzn., že není jednoznačně vymezeno, jak se má postupovat při sestavování SWOT matice. Na chybějící metodiku poukazuje také Valentin (2005). Je sice dáno, že příležitosti a hrozby popisují vnější prostředí a silné a slabé stránky popisují vnitřní prostředí, často jsou také vybrané analýzy vnějšího a vnitřního prostředí samostatně provedeny, nicméně SWOT matice nereflektuje jejich výsledky. Faktory dílčích analýz nejsou vyhodnoceny, resp. není vyhodnocen jejich dopad na podnik.

Jak uvádí Hill a Westbrook (1997), často jsou faktory popsány velmi vágně. Dalším možnými úskalími je právě to, že některé body SWOT matice nevychází z žádné analýzy a že obecně popisují celý podnik, všechny produkty a trhy. Prostředí se navíc vyvíjí velmi rychle a silná stránka nebo př́ležitost může rychle ztratit svůj význam a naopak slabá stránka nebo hrozba nabýt na své intenzitě. Pokud se nechá organizace ukolébat zjištěným stavem a nemonitoruje vývoj okolního prostředí, je provádění SWOT analýzy bezvýznamné (Henry, 2011).

Pokud bychom hledali hlavní prŕíčinu nedostatků SWOT analýzy, tak to není metoda sama o sobě, ale způsob jejího provedení. Proto spíš než na její zavržení by se měly organizace soustředit na zdokonalení jejího provedení. Mnohými autory je označována tato metoda jako oblíbená (Grasseová et al., 2010), a přitom ,jednoduchá“ (Sedláčková, 2000), což může vést k nedbalosti při jejím provádění a na druhé straně k př́lišnému očekávání od zjištěných výsledků.

I přesto, že je SWOT analýza kritizována, a v některých bodech oprávněně, bude použita jako nástroj syntézy vnější a vnitřní strategické analýzy. Budou však navržena opatření, která by tyto nedostatky měla eliminovat. 


\subsection{Externí analýza jako část SWOT analýzy}

V následujícím textu se zaměříme na externí analýzu jako část SWOT analýzy, její obsah a metody, které mohou být základem pro identifikaci př́ležitostí a hrozeb pro vybranou organizaci.

Strategická analýza vnějšího okolí se zabývá identifikací a rozborem faktorů, které působí na organizaci zvnějšku a ovlivňují její činnost a strategické postavení na trhu. Toto působení má jak charakter kladný (přináší organizaci nové možnosti), tak záporný, kdy tyto faktory mohou činnost organizace významně ohrozit. Jak tvrdí Keřkovský a Vykypěl (2006, str. 40), analýza vnějšího prostředí by měla být zaměřena především na odhalení vývojových trendů, které mohou organizaci v budoucnu ovlivňovat.

Okolí lze rozdělit do dvou vrstev, a to na makroprostředí, čímž je myšleno vzdálené okolí podniku, a mikroprostředí, čímž je myšleno oborové okolí podniku (Mallya, 2007). Pro identifikaci vnějších faktorů se využívají např. analýza PESTLE, Porterova analýza pěti konkurenčních sil, analýza zainteresovaných stran, analýza životního cyklu odvětví, analýza „3C“،, analýza atraktivity odvětví a další (Bensoussan, Fleisher, 2012).

\section{Návrh modelu pro vyhodnocení externí části SWOT analýzy}

Na základě vlastního průzkumu, který byl zaměřen na využití strategických nástrojů v malých a středních podnicích a proběhl v roce 2013 v 70 podnicích v Moravskoslezském kraji (Bartusková, 2015, Baurová, Janečko, Papalová, 2013), a studiem literatury (Afonina, 2011, Tassbehji, Isherwood, 2014) bylo zjištěno, že většina organizací strategickou analýzu ve větší či menší míre uplatňuje a nejčastěji je využívána pro charakteristiku vnějšího a vnitřního prostředí SWOT analýza. Tuto analýzu zná, pravidelně nebo občas používá $93 \%$ analyzovaných organizací (Afonina, 2011). Některé společnosti ji dále využívají jako klíčový prvek k formulaci budoucí strategie, u některých je to pouze doplňkový zdroj informací, ale k samotnému stanovení strategie SWOT analýza není využita.

Syntéza výsledků dílčích analýz není jednoduchá a při uplatňování navržených metod se objevují chyby, kterými jsou především chybějící metodika při sestavování SWOT matice a vyhodnocování vlivů jednotlivých faktorů, které se ve SWOT matici objeví.

\subsection{Výběr metod sloužící $k$ analýze vnějšího okolí podniku}

Pro sestavení modelu je využito výsledků z několika průzkumů (Bartusková, 2015, Baurová, Janečko, Papalová, 2013, Afonina, 2011, Tassabehji, Isherwood, 2014), které se zaměřují na využití metod strategické analýzy. Z těch vyplynulo, že pro analýzu vnějšího prostředí jsou používány především PESTLE analýza a Porterova analýza pěti konkurenčních sil. Bylo zjištěno, že některé podniky při aplikaci těchto analýz nevěnují pozornost všem prvkům, které do nich náleží, ale zaměřují se pouze na ty, které odpovídají zaměření jejich obchodní činnosti. V tomto článku je návrh proveden pro organizaci, která si z důvodu zachování anonymity a citlivosti údajů nepřála být jmenována a také jednotlivé faktory, které se v článku objeví, jsou popsány více obecně, než je tomu v existujícím strategickém dokumentu organizace. Nicméně při zpracování modelu manažeři zcela chápou význam jednotlivých faktorů. Tato společnost pracuje s PEST analýzou (faktory legislativní a ekologické nejsou samostatně hodnoceny) a s Porterovou analýzou.

Navržený model bude respektovat výsledky dílčích analýz vnějšího prostředí, kde vstupy jsou analýza makroprostředí PESTLE a mikroprostředí, což je Porterova analýza pěti 
konkurenčních sil. Pro vyhodnocení interní části budou pak navrženy další vhodné analýzy. Graficky bychom mohli toto propojení znázornit na Obrázku 1.

Takto navržený model by však pouze shrnul dohromady poznatky všech analýz. Je tedy nutné navrhnou metodiku pro vyhodnocení důležitosti jednotlivých faktorů.

Obrázek 1: Návrh modelu sestavení SWOT analýzy

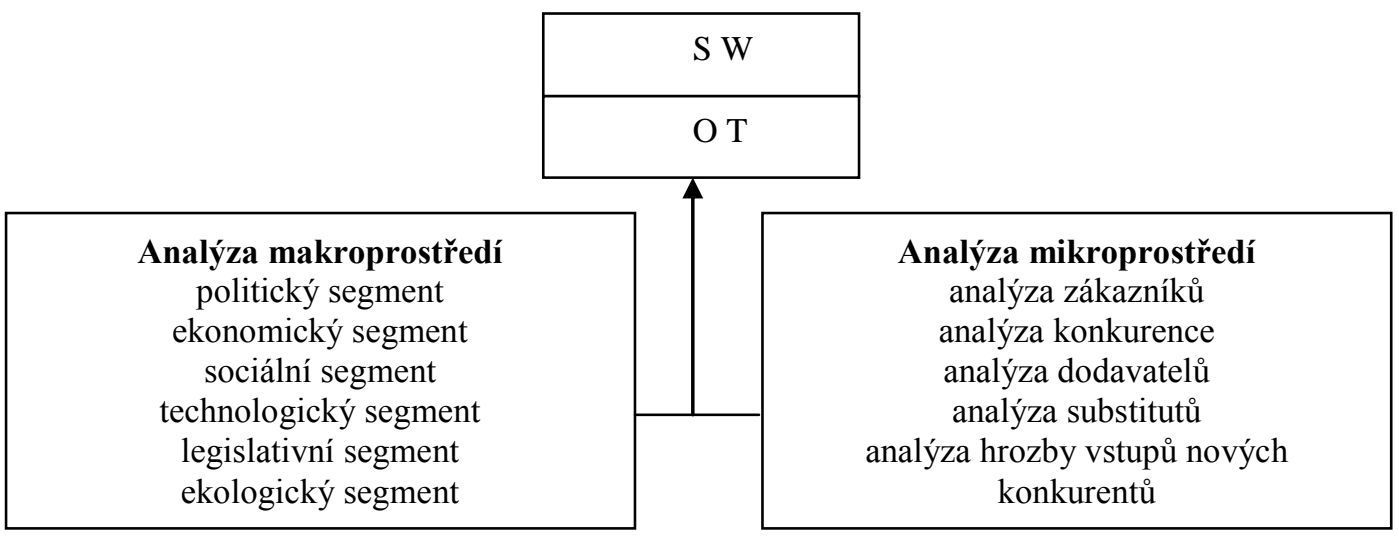

Zdroj: vlastní zpracování

\subsection{Využití metody analytický hierarchický proces (AHP) pro syntézu výsledků} Jak tvrdí Grant (2013, s. 11) nebo Henry (2010, s. 123), nelze vždy každý faktor považovat pouze za př́ležitost nebo ohrožení. Snadno se z jednoho může stát druhý. Je proto nutné zvažovat u každého faktoru, do jaké míry jde o př́ležitost či hrozbu. Proto je vhodné použít metodu AHP, která umožňuje posuzovat výsledné alternativy (př́ležitosti a hrozby) vzhledem ke všem dílčím subkritériím (faktorům SWOT matice).

AHP je metoda vícekriteriálního rozhodování, jež umožňuje rozložení rozhodovacího problému na dílčí komponenty a následné spojení řešení všech sub-komponenti̊ do celkového řešení (Ramík, 1999). Pomocí metody AHP můžeme stanovit jak významnost daného faktoru, tak vybrat, zda bude daný faktor spíš př́ležitostí nebo hrozbou. Výsledkem pak budou prvky SWOT matice, které vzejdou právě z tohoto hodnocení. Vzhledem k tomu, že metodou AHP jsou porovnávány prvky $\mathrm{v}$ každé skupině mezi sebou navzájem, nedojde k prrehlédnutí žádného významného faktoru, stejně tak jako by se neměl do této skupiny dostat faktor zcela bezvýznamný. Je pak na podniku, jaká si nastaví kritéria a kolik faktorů bude chtít mít ve výsledné matici. Tento počet je potřeba dobře zvážit, aby nedošlo také k „přehlcení“ informacemi a následně tak k problémům při vyhodnocování SWOT matice.

\subsubsection{Popis metodiky AHP}

Prvním krokem v tomto rozhodovacím procesu je správné určení hierarchie. Ta je sestavena nejen pro to, aby byly identifikovány všecky rozhodující prvky, ale také vazby mezi nimi. V druhém kroku je nutné stanovit váhy pro jednotlivá kritéria a sub-kritéria s ohledem na cíl rozhodování. Pro určení těchto vah bude použita metoda párového srovnání. Pro správnost celkového rozhodovacího procesu je třeba vyjádřit váhy jednotlivých kritérií s přihlédnutím ke skutečnosti, jak moc ovlivňují dosažení cíle. Pro výpočet vah kritérií je nutné sestavit Saatyho matici o velikosti $k_{n} x k_{n}$, kde $k(k=1,2, \ldots, n)$ jsou jednotlivá kritéria. 


$$
\begin{array}{c|cccc}
\mathrm{k}_{1} & \mathrm{k}_{1} & \mathrm{k}_{2} & \mathrm{k}_{3} & \mathrm{k}_{\mathrm{n}} \\
\mathrm{k}_{2} & \mathrm{~s}_{12} & \mathrm{~s}_{13} & \mathrm{~s}_{1 \mathrm{n}} \\
\mathrm{k}_{3} & 1 / \mathrm{s}_{12} & 1 & \mathrm{~s}_{22} & \mathrm{~s}_{2 \mathrm{n}} \\
\mathrm{k}_{\mathrm{n}} & 1 / \mathrm{s}_{13} & 1 / \mathrm{s}_{23} 1 & \mathrm{~s}_{3 \mathrm{n}} \\
1 / \mathrm{s}_{1 \mathrm{n}} & 1 / \mathrm{s}_{2 \mathrm{n}} & 1 / \mathrm{s}_{3 \mathrm{n}} & 1
\end{array}
$$

Saatyho matice je reciproká, musí tedy platit, že $s_{i, j}=1 / s_{j, i}$. Prvky na diagonále matice jsou vždy rovny hodnotě 1 . Prvky Saatyho matice jsou interpretovány jako odhady podílu vah $i$ tého a j-tého kritéria:

$$
s_{i j} \approx \frac{w_{i}}{w_{j}}
$$

kde $w_{i}$ je váha $i$-tého a $w_{j}$ váha j-tého kritéria.

Pro sestavení Saatyho matice je třeba párově porovnat jednotlivá kritéria. Dominanci jednotlivých kritérií lze vyjádřit pomocí čísel, a to v rozmezí hodnot $1-9$, viz Tabulka 1.

Tabulka 1: Bodová stupnice pro hodnocení kritérií

\begin{tabular}{|l|l|}
\hline Počet bodů & Popis \\
\hline 1 & kritéria jsou stejně významná \\
\hline 3 & první kritérium je slabě významnější než druhé \\
\hline 5 & první kritérium je silně významnější než druhé \\
\hline 7 & první kritérium je velmi silně významnější než druhé \\
\hline 9 & první kritérium je absolutně významnější než druhé \\
\hline $2,4,6,8$ & $\begin{array}{l}\text { sudý počet bodů vyjadřuje mezistupně a slouží } \mathrm{k} \text { jemnějšímu rozlišení } \\
\text { preferencí }\end{array}$ \\
\hline
\end{tabular}

Zdroj: Saaty (1994)

Ve třetím kroku je potřeba zjistit koeficient konzistence matice. Ten vypovídá o tom, zda je matice správně sestavená a musí to být ověřeno před samostatným výpočtem. Konzistentnost se dá posoudit pomocí koeficientu konzistence $C R$ (Consistency Ratio), prričemž za konzistentní se považuje hodnota $C R \leq 0,1$. Tento koeficient se spočte na základě vztahu:

$$
C R=\frac{C I}{R I}
$$

Přitom

$$
C I=\frac{\lambda \max -n}{n-1}
$$

kde $n$ je počet kritérií a $\lambda_{\max }$ je nejvyšší vlastní číslo matice, vypočtené jako

$$
\lambda_{\max }=\sum_{i=1}^{n} \frac{(\mathbf{S} \cdot \vec{w})_{i}}{n \cdot w_{i}},
$$

kde $\vec{w}$ je vektor a $(\mathbf{S} \cdot \vec{w})_{\mathrm{i}}$ je i-tý prvek vektoru. RI je index náhodnosti, který je závislý na počtu prvků matice a byl určen na základě výzkumu (Saaty, 1994), viz Tabulka 2. 
Tabulka 2: Hodnoty RI pro různý počet prvků

\begin{tabular}{|l|c|c|c|c|c|c|c|c|c|c|}
\hline$n$ & 1 & 2 & 3 & 4 & 5 & 6 & 7 & 8 & 9 & 10 \\
\hline$R I$ & 0 & 0 & 0.58 & 0.90 & 1.12 & 1.24 & 1.32 & 1.41 & 1.45 & 1.49 \\
\hline
\end{tabular}

Zdroj: Saaty (1994)

Je-li $C R \leq 0,1$, pak lze Saatyho matici párových srovnání považovat za dostatečně konzistentní a je možno pokračovat ve výpočtu vah jednotlivých kritérií.

\subsubsection{Výpočet vah jednotlivých kritérií}

Váhy mohou být zjištěny pomocí kvadratického programování nebo logaritmické verze kvadratického programování. Jednou z nejjednodušších metod určení vah kritérií, která je snadno řešitelná $\mathrm{v}$ praxi, je metoda využívající váženého geometrického průměru řádků Saatyho matice

$$
w_{i}=\frac{\left[\prod_{j=1}^{n} s_{i j}\right]^{\frac{1}{n}}}{\sum_{i=1}^{n}\left[\prod_{j=1}^{n} s_{i j}\right]^{\frac{1}{n}}} .
$$

Stejně se postupuje níže v hierarchii, kdy jsou obdobným způsobem určeny lokální váhy dílčích sub-kritérií a s ohledem na nadřazené kritérium jsou vypočteny globální váhy těchto sub-kritérií (Ramík, 1999, Saaty, 1994).

\subsubsection{Popis jednotlivých kroků metodiky pro vybranou organizaci}

Postup zpracování pro syntézu výsledků externí analýzy lze rozdělit do těchto kroků:

1) Nejprve je nutné správně určit hierarchii. Tato je naznačena v Obrázku 2. Nejprve budou párovým srovnáním porovnány samotné metody PEST a Porterova analýza. Pak následuje srovnání dílčích faktorů $\mathrm{v}$ rámci každé metody a následně dojde $\mathrm{k}$ porovnání jednotlivých konkrétních vlivů (tyto nejsou v Obrázku 2 zaznačeny, protože by to snižovalo přehlednost celé situace). Bude porovnán každý faktor s každým faktorem a bude určeno, kolikrát je jeden faktor významnější než druhý. Faktory jsou umístěny do reciproké matice a v ní jsou vzájemně srovnávány.

2) Je nutné, aby každá matice byla konzistentní, což vypovídá o tom, že je matice správně sestavena. V našem př́ípadě byla konzistentnost u všech matic dodržena.

3) Vždy postupujeme od lokálních hodnot zjištěných vah k hodnotám globálním (ty berou v úvahu vždy výsledky nadřazeného kritéria).

4) V závěru dojde k porovnání možných variant vzhledem ke každému dílčímu kritériu. To znamená, že bude hodnoceno, zda výsledný faktor je pro organizaci př́ležitostí nebo hrozbou. 
Obrázek 2: Grafické znázornění AHP pro vyhodnocení vlivu jednotlivých faktorů

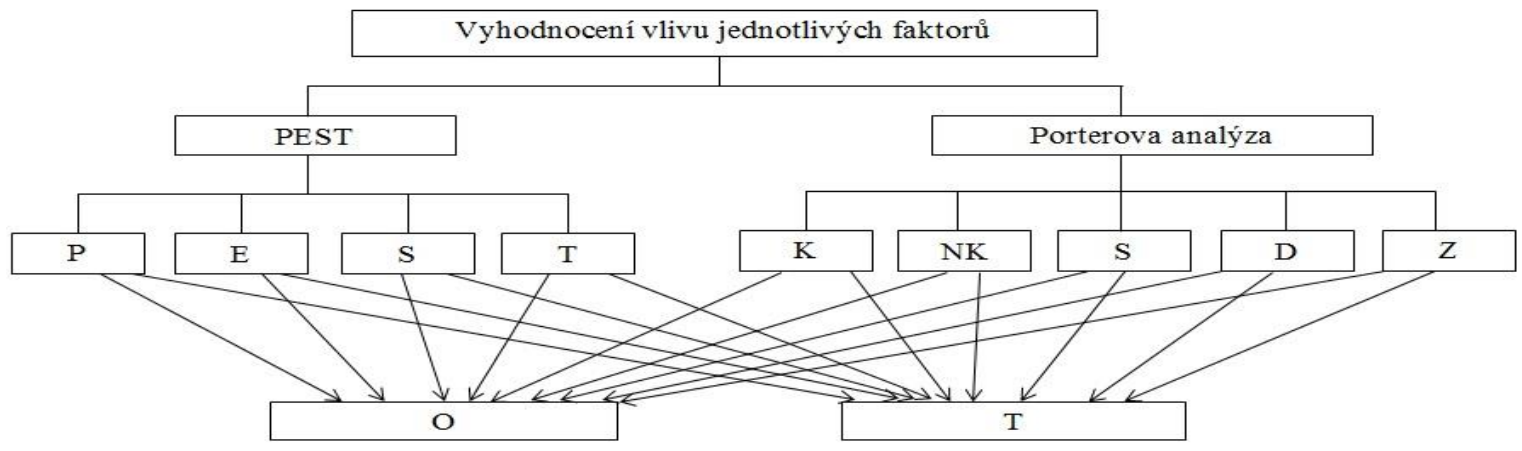

Zdroj: vlastní zpracování

Při návrhu modelu jsme spolupracovali s manažery dané organizace, kteří prováděli vyhodnocení pro tuto konkrétní situaci.

\subsection{Postup zpracování modelu pro vybranou organizaci}

Organizace, ve které byl model zpracován, provádí v rámci externí analýzy PEST analýzu a Porterovu analýzu. Pokud tedy využijeme metodu AHP, kritérii se stanou jednotlivé metody a sub-kritérii jejich dílčí faktory. V Obrázku 2 jsou znázorněny metody jako kritéria (PEST a Porterova analýza) a sub-kritéria (faktor politicko-legislativní, ekonomický, sociální, technologický, konkurence, nová konkurence, substituty, dodavatelé a zákazníci). Společnost sama provedla PEST analýzu a Porterovu analýzu konkurenčních sil. Její výsledky lze vidět v Tabulce 3 a v Tabulce 4.

Tabulka 3: PEST analýza

\begin{tabular}{|l|l|l|l|}
\hline \multirow{2}{*}{ Politické faktory } & Ekonomické faktory & Sociální faktory & Technologické faktory \\
\hline \multirow{2}{*}{ Sazba DPH } & Pokles HDP & Demografická & Nízkoenergetické domy \\
\cline { 2 - 2 } & Pokles stavebních prací & \multirow{2}{*}{ Struora } & Nové odlehčené materiály \\
\hline Odvody státu & Míra inflace & \multirow{2}{*}{ Sofistikované výrobky } \\
\hline Zahraniční obchod & Nezaměstnanost & \\
\hline
\end{tabular}

Zdroj: vlastní zpracování

Tabulka 4: Porterova analýza konkurenčních sil

\begin{tabular}{|c|c|c|c|c|}
\hline Konkurence & Nová konkurence & Zákazníci & Dodavatelé & Substituty \\
\hline $\begin{array}{l}\text { Vyšší kvalita oproti } \\
\text { konkurenci z Turecka a } \\
\text { Číny }\end{array}$ & $\begin{array}{l}\text { Nové závody v } \\
\text { Asii }\end{array}$ & $\begin{array}{l}\text { Jen evropský trh, } \\
\text { neznalost jiných trhů }\end{array}$ & \multirow{4}{*}{$\begin{array}{l}\text { Existence } \\
\text { stabilního zdroje, } \\
\text { nepředpokládá se } \\
\text { prudká změna } \\
\text { ceny }\end{array}$} & \multirow{4}{*}{ Plechové kotle } \\
\hline \multirow{3}{*}{$\begin{array}{l}\text { Vysoký tržní podíl } \\
\text { konkurentů }\end{array}$} & \multirow{3}{*}{$\begin{array}{l}\text { Nevyužité kapacity } \\
\text { konkurence }\end{array}$} & $\begin{array}{l}\text { Možnost zakázek na } \\
\text { míru }\end{array}$ & & \\
\hline & & Dobrá podpora prodeje & & \\
\hline & & $\begin{array}{l}\text { Vyšší cena některých } \\
\text { produktů }\end{array}$ & & \\
\hline
\end{tabular}

Zdroj: vlastní zpracování

Nejprve byly párově porovnány jednotlivé metody a byly stanoveny jejich váhy. Výsledky můžeme vidět $v$ Tabulce 5 . Pokud se při aplikaci metody AHP stane to, že porovnáváme pouze dva prvky, tak platí, že matice je vždy konzistentní. Není tedy potřeba počítat koeficient konzistence CR. 
Tabulka 5: Párové porovnání metod externí analýzy

\begin{tabular}{|c|c|c|}
\hline & $\begin{array}{c}\text { Porterova } \\
\text { analýza }\end{array}$ & PESTLE \\
\hline Porterova analýza & 1 & 2 \\
\hline PESTLE & $1 / 2$ & 1 \\
\hline
\end{tabular}

\begin{tabular}{|c|c|c|c|}
\hline $\begin{array}{c}\text { geometr. } \\
\text { průměr }\end{array}$ & váhy & $\mathrm{S} \cdot \mathrm{w}$ & $(\mathrm{S} \cdot \mathrm{w})_{\mathrm{i}} / \mathrm{w}_{\mathrm{i}}$ \\
\hline 1.414 & 0,667 & 1.333 & 2.000 \\
\hline 0.707 & 0,333 & 0.667 & 2.000 \\
\hline
\end{tabular}

Zdroj: vlastní zpracování

Poté byla porovnána jednotlivá sub-kritéria v každé kategorii. Nejprve byly porovnány faktory PEST a poté faktory Porterovy analýzy konkurenčních sil. Vzhledem k rozsáhlosti výpočtů, které byly provedeny na základě výše popsané metodiky a ke kterým bylo využito programu MS Excel, nejsou tyto výpočty součástí článku. Jednotlivé váhy jsou uvedeny v Tabulce 6.

Tabulka 6: Lokální a globální váhy dílčích kritérií

\begin{tabular}{|l|c|c|}
\hline & Lokální váha (\%) & Globální váha (\%) \\
\hline Porterova analýza & 66,67 & \\
\hline PEST & 33,33 & \\
\hline Konkurence & 26,99 & 18,00 \\
\hline Nová konkurence & 5,50 & 3,66 \\
\hline Zákazníci & 49,63 & 33,09 \\
\hline Dodavatelé & 14,68 & 9,79 \\
\hline Substituty & 3,20 & 2,13 \\
\hline Politické vlivy & 15,04 & 5,01 \\
\hline Ekonomické vlivy & 26,05 & 8,68 \\
\hline Sociální vlivy & 7,64 & 2,55 \\
\hline Technologické vlivy & 51,27 & 17,09 \\
\hline
\end{tabular}

Zdroj: vlastní zpracování

Následně došlo k porovnání další úrovně sub-kritérií v rámci každého nadřazeného faktoru. Nejprve byly porovnány sub-kritéria metody PEST. Výsledné váhy vidíme v Tabulce 7 . Byly stanoveny lokální a globální váhy jednotlivých sub-kritérií. Pro výpočet globální váhy je potřeba roznásobit dílčí sub-kritérium váhou nadřazeného kritéria.

Tabulka 7: Lokální a globální váhy subkritérií PEST analýzy

\begin{tabular}{|l|c|c|}
\hline & Lokální váha (\%) & Globální váha (\%) \\
\hline Sazba DPH & 27,90 & 1,40 \\
\hline Odvody státu & 7,19 & 0,36 \\
\hline Zahraniční obchod & 64,91 & 3,25 \\
\hline Pokles HDP & 11,27 & 0,98 \\
\hline Pokles stavebních prací & 61,29 & 5,32 \\
\hline Míra inflace & 5,26 & 0,46 \\
\hline Nezaměstnanost & 22,18 & 1,93 \\
\hline Demografická struktura & 66,67 & 1,70 \\
\hline Průměrná mzda & 33,33 & 0,85 \\
\hline Nízkoenergetické domy & 61,44 & 10,50 \\
\hline Nové odlehčené materiály & 26,84 & 4,59 \\
\hline Sofistikované výrobky & 11,72 & 2,00 \\
\hline
\end{tabular}

Zdroj: vlastní zpracování

Dále došlo k porovnání sub-kritérií Porterovy analýzy. Výsledky vidíme v Tabulce 8. 
Tabulka 8: Lokální a globální váhy subkritérií Porterovy analýzy

\begin{tabular}{|l|c|c|}
\hline & Lokální váha (\%) & Globální váha (\%) \\
\hline $\begin{array}{l}\text { Vyšší kvalita oproti konkurenci z } \\
\text { Turecka a Č́ny }\end{array}$ & 33,33 & 6,00 \\
\hline Vysoký tržní podíl konkurentů & 66,67 & 12,00 \\
\hline Nové závody v Asii & 75,00 & 2,75 \\
\hline Nevyužité kapacity konkurence & 25,00 & 0,92 \\
\hline Jen evropský trh, neznalost jiných trhů & 29,29 & 9,69 \\
\hline Možnost zakázek na míru & 10,15 & 3,36 \\
\hline Dobrá podpora prodeje & 55,18 & 18,26 \\
\hline Vyšší cena některých produktů & 5,39 & 1,78 \\
\hline $\begin{array}{l}\text { Existence stabilního zdroje, } \\
\text { nepředpokládá se prudká změna ceny }\end{array}$ & 100,00 & 9,79 \\
\hline Plechové kotle & 100,00 & 2,13 \\
\hline
\end{tabular}

Zdroj: vlastní zpracování

V posledním kroku je potřeba určit, zda je daný faktor pro podnik spíše př́ležitost nebo spíše hrozba. Budeme tedy rozhodovat u každého faktoru, kolikrát více je př́ležitostí než hrozbou a naopak. Výsledkem je váha u každé z těchto alternativ. Poté roznásobíme tyto váhy globální váhou každého faktoru, která byla vypočtena v předchozím kroku. Tím získáme konečný výsledek, který nám pomůže sestavit výslednou SWOT matici, resp. její část definující př́ležitosti a ohrožení. Výsledky vidíme v Tabulce 9.

Tabulka 9: Souhrnné výsledky pro definici př́iležitostí a ohrožení

\begin{tabular}{|c|c|c|c|c|c|c|}
\hline \multirow[t]{2}{*}{ Faktor } & \multirow{2}{*}{$\begin{array}{c}\text { Lokální } \\
\text { váha } \\
(\%)\end{array}$} & \multirow{2}{*}{$\begin{array}{c}\text { Globální } \\
\text { váha } \\
(\%)\end{array}$} & \multicolumn{2}{|c|}{ Váha alternativy (\%) } & \multicolumn{2}{|c|}{$\begin{array}{l}\text { Globální váha } \\
\text { alternativy }(\%)\end{array}$} \\
\hline & & & $\mathrm{O}$ & $\mathrm{T}$ & $\mathrm{O}$ & $\mathrm{T}$ \\
\hline $\begin{array}{l}\text { Vyšší kvalita oproti konkurenci z } \\
\text { Turecka a Číny }\end{array}$ & 33,33 & 6,00 & 87,50 & 12,50 & 5,25 & 0,75 \\
\hline Vysoký tržní podíl konkurentů & 66,67 & 12,00 & 12,50 & 87,50 & 1,50 & 10,50 \\
\hline Nové závody v Asii & 75,00 & 2,75 & 16,67 & 83,33 & 0,46 & 2,29 \\
\hline Nevyužité kapacity konkurence & 25,00 & 0,92 & 25,00 & 75,00 & 0,23 & 0,69 \\
\hline Jen evropský trh, neznalost jiných trhů & 29,29 & 9,69 & 16,67 & 83,33 & 1,62 & 8,08 \\
\hline Možnost zakázek na míru & 10,15 & 3,36 & 90,00 & 10,00 & 3,02 & 0,34 \\
\hline Dobrá podpora prodeje & 55,18 & 18,26 & 83,33 & 16,67 & 15,21 & 3,04 \\
\hline Vyšší cena některých produktů & 5,39 & 1,78 & 16,67 & 83,33 & 0,30 & 1,48 \\
\hline $\begin{array}{l}\text { Existence stabilního zdroje, } \\
\text { nepředpokládá se prudká změna ceny }\end{array}$ & 100,00 & 9,79 & 87,50 & 12,50 & 8,57 & 1,22 \\
\hline Plechové kotle & 100,00 & 2,13 & 16,67 & 83,33 & 0,36 & 1,78 \\
\hline Sazba DPH & 27,90 & 1,40 & 16,67 & 83,33 & 0,23 & 1,17 \\
\hline Odvody státu & 7,19 & 0,36 & 20,00 & 80,00 & 0,07 & 0,29 \\
\hline Zahraniční obchod & 64,91 & 3,25 & 83,33 & 16,67 & 2,71 & 0,54 \\
\hline Pokles HDP & 11,27 & 0,98 & 12,50 & 87,50 & 0,12 & 0,86 \\
\hline Pokles stavebních prací & 61,29 & 5,32 & 10,00 & 90,00 & 0,53 & 4,79 \\
\hline Míra inflace & 5,26 & 0,46 & 16,67 & 83,33 & 0,08 & 0,38 \\
\hline Nezaměstnanost & 22,18 & 1,93 & 12,50 & 87,50 & 0,24 & 1,69 \\
\hline Demografická struktura & 66,67 & 1,70 & 16,67 & 83,33 & 0,28 & 1,42 \\
\hline Průměrná mzda & 33,33 & 0,85 & 83,33 & 16,67 & 0,71 & 0,14 \\
\hline Nízkoenergetické domy & 61,44 & 10,50 & 83,33 & 16,67 & 8,75 & 1,75 \\
\hline Nové odlehčené materiály & 26,84 & 4,59 & 87,50 & 12,50 & 4,01 & 0,57 \\
\hline Sofistikované výrobky & 11,72 & 2,00 & 83,33 & 16,67 & 1,67 & 0,33 \\
\hline
\end{tabular}

Zdroj: vlastní zpracování

Jak je z tabulky patrné, tak vybrané faktory jsou především silně ovlivněny jejich globálními vahami. Je možné si všimnout, že pokud je globální váha a tedy vliv jednoho z faktorů natolik 
silný, může se stát, že je faktor zařazen jak do skupiny př́ležitostí, tak do skupiny hrozeb. Zde je třeba zvážit, nakolik patři jen do jedné skupiny, nebo zda by mu bylo dobré věnovat pozornost i ve skupině druhé. Toto rozhodnutí je vždy na manažerech organizace. Toto se stalo např. u faktoru dobrá podpora prodeje a nízkoenergetické domy. U obou těchto faktorů bylo vyhodnoceno, že jde o príležitosti pro danou organizaci a takto také budou posuzovány. Externí část výsledné SWOT matice bude tedy pak vypadat následovně, viz Tabulka 10.

Tabulka 10: Externí část SWOT matice

\begin{tabular}{|l|l|}
\hline \multicolumn{1}{|c|}{ Př́ležitosti } & \multicolumn{1}{c|}{ Hrozby } \\
\hline Vyšší kvalita oproti konkurenci z Turecka a Číny & Vysoký tržní podíl konkurentů \\
\hline Možnost zakázek na míru & Nové závody v Asii \\
\hline Dobrá podpora prodeje & Jen evropský trh, neznalost jiných trhů \\
\hline Existence stabilního zdroje, nepředpokládá se prudká změna ceny & Plechové kotle \\
\hline Zahraniční obchod & Pokles stavebních prací \\
\hline Nízkoenergetické domy & \\
\hline Nové odlehčené materiály & \\
\hline
\end{tabular}

Zdroj: vlastní zpracování

\section{Diskuze}

Je důležité zamyslet se nad praktickým postupem této metodiky $\mathrm{v}$ organizaci a nad jejím omezením. Výše představena metodika může pomoct manažerům podniku při sestavování matice. Výhodou tohoto postupu je to, že nebude opomenut žádný z faktorů, který by měl na výsledek vliv a také to, že metoda AHP umožňuje i skupinové rozhodování, kdy všem členům (rozhodovatelům) lze přiřadit stejnou nebo různou váhu při jejich rozhodování. Nevýhodou může být na první pohled složitější postup zpracování. Tato nevýhoda však určitě není nepřekonatelná. Jednak k hodnocení vnějšího prostředí a úpravě strategií nedochází tak často, takže toto rozhodování bude organizace provádět maximálně jednou za rok nebo za dva roky. Pokud jsou připraveny výsledky dílčích analýz, které plynou z dat společnosti, není problém je zapracovat do prŕslušných tabulek a pomocí programu Excel vyhodnotit. Výsledky poté budou sloužit jako vodítko pro manažery při sestavení SWOT matice. Stejným způsobem bychom mohli postupovat, pokud bychom chtěli rozhodovat o vyhodnocení interní části SWOT matice.

Pokud bychom konfrontovali námi získané výsledky s výsledky organizace, která poskytla data a sama SWOT matici sestavila, tak bychom zjistili, že v některých bodech společnost dospěla ke stejnému výsledku (bez použití navržené metodiky). Jde např. o faktory z řady př́ležitostí, kterými jsou možnost zakázek na míru, využití nových materiálů, a faktory z řady hrozeb, kterými jsou nové závody v Asii a vysoký tržní podíl konkurentů. V prŕípadě, že organizace bude definovat jiné faktory, než jsou vyhodnoceny touto metodikou, tak je potřeba zjistit, zda všichni členové, kteří o tom rozhodují, chápou daný faktor stejně a zda nedošlo při jeho hodnocení např. k nepochopení. V našem př́ípadě došlo k hodnocení situace dvěma manažery podniku, kteří společně vyplňovali danou matici.

\section{Závěr}

Cílem článku bylo navrhnout vyhodnocení dílčích výsledků externí analýzy tak, aby bylo možné identifikovat př́ležitosti a hrozby podniku. Byla představena strategická analýza a vymezen její význam pro organizaci a byla popsána SWOT analýza, její prínos a kritické aspekty. Poté byla věnována pozornost především externí části SWOT analýzy. Na základě vlastního šetření a literatury byly vymezeny metody strategické analýzy, které slouží jako podklad pro zpracování externí části SWOT matice, tedy k identifikaci př́ležitostí a hrozeb podniku. Následně byla navržena a na konkrétních datech organizace zpracována metodika, 
která využívá metody AHP. Pomocí této metodiky lze rozhodnout, které z faktorů budou ve SWOT matici jako př́ležitosti a hrozby. Nakonec je sestavena externí část SWOT matice. Na vyhodnocení modelu se podíleli manažeři vybrané organizace.

Jak je patrné z výsledků, Porterova analýza, která analyzuje blízké okolí podniku, bude mít na výběr daných faktorů vetší vliv než PEST analýza. Na zkoumanou organizaci působí především vliv zákazníků, konkurence a technologické vlivy. Tato skutečnost bude také ovlivňovat konečné postavení daných faktorů v externí části SWOT matice. Nejvýznamněji budou na společnost působit „Dobrá podpora prodeje“ a „Nízkoenergetické domy“ jako př́ležitost a „Vysoký tržní podíl konkurentư“ jako hrozba. Při využití této metodiky je možné do rozhodování zapojit více členů organizace, kteří mohou mít na výsledné rozhodovaní stejný nebo různý vliv.

\section{Poděkování}

Tento článek vznikl za podpory grantu - SGS SP2015/93 Aplikace hybridních vícekriteriálních metod v oblasti podnikové ekonomiky, managementu a marketingu.

\section{Literatura:}

[1] AFONINA, A., 2011. Strategic management tools usage. In: International workshop for PhD Students. Brno: VUT. ISBN 978-80-214-4348- 8.

[2] BARTUSKOVÁ, T., 2014. Využití metod strategické analýzy při sestavení SWOT matice. In: Mezinárodní védecká konference Hradecké ekonomické dny 2015. Hradec Králové: Gaudeamus, s. 45-54. ISBN 978-80-7435-546-2.

[3] BAUROVÁ, V., M. JANEČKO a M. PAPALOVÁ, 2013. The Influence of Corporate External Environment on Strategy. In: PEFNet 2013: European scientific conference of Ph.D. students: 17th Year, November 21, 2013. Brno: Mendelova Universita, s. 25-32, ISBN 978-80-7375-906-3.

[4] BENSOUSSAN, B. E. a C. S. FLEISHER, 2013. Analysis without paralysis: 12 tools to make better strategic decisions. 2nd ed. New Jersey: FT Press. ISBN 978-0-133101-027.

[5] FERRELL, O. C. a M. D. HARTLINE, 2014. Marketing strategy: text and cases. 6th ed. Mason: South-Western/Cengage Learning. ISBN 12-850-7304-5.

[6] FOTR, J. et al., 2012. Tvorba strategie a strategické plánování: teorie a praxe. Praha: Grada. ISBN 978-80-247-3985-4.

[7] GRANT, R. M., 2013. Contemporary strategy analysis: text and cases. 8th ed. Chichester: Wiley. ISBN 978-1-119-94189-7.

[8] GRASSEOVÁ, M. et al., 2010. Analýza podniku v rukou manažera. Brno: Computer Press. ISBN 978-80-251-2621-9.

[9] GRIFFIN, R. W., 2008. Fundamentals of management. 5th ed. Boston: Houghton Mifflin. ISBN 06-189-1707-1.

[10] HENRY, A., 2011. Understanding strategic management. 2nd ed. New York: Oxford University Press. ISBN 978-0-19-958161-0.

[11] HILL, T. a R. WESTBROOK, 1997. SWOT Analysis: It's Time for a Product Recall. Long Range Planning [online]. 30(1), 46-52 [cit. 2014-11-10]. ISSN 0024-6301. Dostupné z: http://www.repiev.ru/doc/SWOT-product-recall.pdf 
[12] KEŘKOVSKÝ, M. a O. VYKYPĚL, 2006. Strategické ř́zení: teorie pro praxi. 2. vyd. Praha: C. H. Beck. ISBN 80-7179-453-8.

[13] MALLYA, T., 2007. Základy strategického ř́zení a rozhodování. Praha: Grada. ISBN 978-80-247-1911-5.

[14] RAMÍK, J., 1999. Vicekriteriální rozhodování - analytický hierarchický proces (AHP). Karviná: Slezská univerzita v Opavě. ISBN 80-7248-047-2.

[15] SAATY, T. L., 1994. Fundamentals of Decision Making and Priority Theory with the Analytic Hierarchy Process. Pittsburgh: RWS Publications. ISBN 09-620-3176-3.

[16] SEDLÁČKOVÁ, H., 2000. Strategická analýza. Praha: C. H. Beck. ISBN 80-7179-4228.

[17] TASSBEHJI, R. a A. ISHERWOOD, 2014. Management Use of Strategic Tools for Innovating During Turbulent Times. Strategic Change, 23(1-2), 63/80. DOI: $10.1002 /$ jsc. 1960

[18] VALENTIN, E. K., 2005. Away with SWOT analysis: Use Defensive/Offensive Evaluation Instead. The Journal of Applied Business Researc, 21(2), 91-105. ISSN 21578834.

[19] WILLIAMSON D. et al, 2004. Strategic management and business analysis. Amsterdam: Butterworth-Heineman. ISBN 978-075-0642-958. 